\title{
The Effect of Perception about The Educational Services Quality and Organizational Environment on Students' Achievement Motivation in Environmental Health Department
}

\author{
Ismi Trihardini $^{1)}, \mathrm{M} \mathrm{Asrori}^{2)}, \mathrm{M}$ Syukri ${ }^{3)}$ \\ ${ }^{1)}$ Universitas Tanjungpura, Pontianak, Indonesia \\ E-mail: ismi_3yani@yahoo.co.id \\ ${ }^{2)}$ Universitas Tanjungpura, Pontianak, Indonesia \\ E-mail: asroriuntan@yahoo.com \\ ${ }^{3)}$ Universitas Tanjungpura, Pontianak, Indonesia \\ E-mail:syukri_fkip@yahoo.com
}

\begin{abstract}
Achievement motivation is an urge in a person to compete and become superior. Achievement motivation is needed so that students have the drive to compete with excellence standards, where this achievement motivation plays a role in developing activities and initiatives, directing and maintaining perseverance in learning activities. Motivation between one student and another student is different due to different perceptions of the quality of educational services. The environment around the education process that can be said as a conducive organizational environment plays a role in increasing the drive for the achievement of students. This study aims to describe and analyze the influence of perceptions about the quality of education services and organizational environment on achievement motivation. The approach in this study is quantitative in the form of causal studies, a sample of 68 students in the Department of Environmental Health of the Ministry of Health of Pontianak were taken using the proportionate stratified random sampling technique. Data retrieval is done by using a research instrument in the form of questionnaire which refers to the Likert scale. Data were analyzed using Rank Spearman test and Linear Regression. Descriptive analysis explained that perception variables about the quality of education services and organizational environment were very good, and achievement motivation was very high. The results of correlation analysis describe 1) student perceptions about the quality of education services significantly influence achievement motivation $(\mathrm{r}=0.445), 2)$ Organizational environment significantly influences achievement motivation $(r=0.767) 3$ ) Student perceptions of the quality of educational services and organizational environment collectively have a significant effect on student achievement motivation in the Department of Health Polytechnic of the Ministry of Health of Pontianak $(R=0.779)$. Conclusions from this study are student perceptions of the quality of education services and organizational environment affect the achievement motivation. Based on the results of the study, it is suggested that the Health Department of Pontianak Health Ministry Polytechnic should continue to maintain or even improve the quality of education services and organizational environment by taking into account the advice provided by the school component through the suggestion box.
\end{abstract}

Keywords: Perception; Quality of Education Service; Organizational Environment; Achievement Motivation

\section{INTRODUCTION}

Education is the basis for improving and preparing quality and competitive Human Resources (HR). The measure of success in quality in the world of education is quality graduates. The quality of graduates according to Bastian (2006: 191) is illustrated by three things, namely the head or head which symbolizes intelligence, hand or hand which symbolizes skill, and heart or heart which symbolizes character and morals. This quality graduate can be realized if you have a positive urge to participate in activities during the education period. 
As explained by Mulyana (2016) that achievement motivation is needed so that students have the urge to compete with the standard of excellence, where this standard of excellence can be in the form of perfection of tasks, can be from themselves or other people's achievements to obtain the higher achievement. This motivation plays an important role in developing activities and initiatives, directing and maintaining perseverance in learning activities.

Students who have achievement motivation will become quality graduates who become one of the indicators of the quality of education services in an educational institution. The quality of education services is a guarantee of the process or service of providing education in educational institutions in accordance with established standards and able to meet customer needs in this case students, the needs of users (users) or the needs of stakeholders related to customer satisfaction (Maswardi M.Amin, 2016: 122) Students are parties that are directly related to the quality of education services provided by an educational institution.

The satisfaction of students about the quality of education services depends on the students' perceptions of the education services they receive. It is in line with that presented by Linu Shajahan (in Setya, 2015: 33) that perception is a basic cognitive or psychological process that will describe a person's feelings towards the surrounding environment that will affect actions, emotions, and thoughts. Similarly, students' perceptions of the quality of education services according to Muntamah (2012), that between one student and another student will vary, so this will also cause differences in the motivation or motivation of the student to carry out activities in the learning process.

The form of educational services in educational institutions is a learning service in which there is a reciprocal relationship between educators and students. This reciprocal relationship is influenced by how students' perceptions of the scope of education include infrastructure as supporting teaching and learning activities, lecturers as educators, and other supporting personnel who are in the education sector.

Another factor that influences achievement motivation in students is the organizational environment or organizational atmosphere that is seen, thought out, and felt by components within the educational institution that are expected to create a conducive, persuasive and educative organizational atmosphere. It is in line with research findings which also show that the healthier or better the school environment, the higher the level of student achievement at the school. (Hoy and Miskel, 2014; 325).

The era of globalization is increasingly critical of the quality of health services. In an effort to produce high-quality health services, the quality of human health resources needs to be improved through the development of quality educational institutions. Health Ministry Polytechnic of Pontianak (Pontianak Ministry of Health Poltekkes) is the only government-owned educational institution under the auspices of the Ministry of Health in West Kalimantan. Pontianak Health Ministry Polytechnic has a role in producing skilled health workers who are able to compete in the world of work. Pontianak Health Ministry Polytechnic oversees six departments, namely Environmental Health Department, Health Analyst Department, Nutrition Department, Dental Nursing Department, Midwifery Department, and Nursing Department.

Among the six majors, the Environmental Health Department is the only one to get the "A" accreditation of the National Higher Education Accreditation Board (BAN-PT). Therefore it can be said that the quality of education services is very good. However, this is not in line with the achievement of the student's grade point average (GPA). The results of the learning evaluation of the Ministry of Health Poltekkes Department of Environmental Health Pontianak Odd Semester 2016/2017 Academic Year shows that students who have a GPA below 2.75 are $16.7 \%$, GPA $2.75-3.00$ as much as $25.1 \%$, GPA 3.01-3.25 as much as $10.9 \%$, and GPA above 3.25 as much as $47.3 \%$. Exposure to the results of the learning evaluation illustrates that the quality of students is still much below the standard or can be said to have not achieved satisfactory results. It is because the IPK target for the Poltekkes as a Public Service Agency (BLU) which is a requirement of the Ministry of Finance is as much as $70 \%$ for a GPA above 3.25 .

In addition, the globalization era also demands quality graduates that can be drawn from the GPA. Learning evaluation results that are considered to have not shown satisfactory results should be able to be reduced at a lower number because the Environmental Health Department is the only department in the Pontianak Ministry of Health Poltekkes that has obtained A accreditation which describes the quality of good education services that support the learning process to be of high quality .

Based on the explanation above, this study was conducted to examine more deeply the "influence of perceptions about the quality of education services and organizational environment on student achievement motivation in the Department of Environmental Health, Pontianak Health Ministry Polytechnic."

\section{RESEARCH METHOD}

This study uses a quantitative approach in the form of causal studies, namely the influence between variables that aims to test the validity of the 
hypothesis relating to the influence of perceptions about the quality of academic services (X1) on achievement motivation (Y) and the influence of organizational environment (X2) on achievement motivation ( $\mathrm{Y}$ ), as well as the influence of perceptions about the quality of academic services (X1) and organizational environment (X2) jointly on achievement motivation (Y).

In this study, the population is all students of the Department of Health at the Pontianak Health Ministry Polytechnic. Determination of the number of samples with a confidence level of $95 \%$ or an error rate of $5 \%$, and by proportionate stratified random sampling, the number of samples was 68 people.

In this study using three variables to be studied, three research instruments will be needed in the form of questionnaire which refers to the Likert scale (very appropriate, appropriate, inappropriate, and very inappropriate), namely:

a. Questionnaire to measure perception variables about the quality of education services

b. Questionnaire to measure organizational environment variables

c. Questionnaire to measure achievement motivation variables

The questionnaire is made through instrument lattice where each research variable is grouped into subvariables, then disseminated into indicators so that the data obtained is directed to the research objectives.

\section{A. Result}

\section{RESUlT AND DISCUSSION}

The data in this study consisted of three variables: Perception about the Quality of Education Services (X1), Organizational Environment (X2), and Achievement Motivation variables (Y). Perception Variables About Quality of Education Services and Organizational Environment are independent variables while Achievement Motivation is dependent variable. The sample taken in this study were 68 students at the Pontianak Department of Health Poltekkes Environmental Health Department. The data description of each variable based on the results of the distribution of the questionnaire will be explained further below:

1. Perceptions of the Quality of Education Services in the Environmental Health Department of the Pontianak Ministry of Health Poltekkes

The perception variable about the quality of education services consists of 39 items of statement items using four choice scales (1-4). Based on the results of statistical analysis, perceptions about the quality of education services can be grouped into four categories: poor with a range of total scores $(0-39)$, moderate (40 - 79), good (80 - 119), and very good (120-156).

The frequency distribution grouping as can be seen in Table I.
Table I

Frequency Distribution of Perceptions about the Quality of Education Services by Category

\begin{tabular}{cllcc}
\hline No & Category & Score Range & Frequency & Percentage \\
\hline 1 & Poor & $0-39$ & 0 & 0 \\
\hline 2 & Fair & $40-78$ & 0 & 0 \\
\hline 3 & Good & $79-117$ & 21 & 30,88 \\
\hline 4 & Very Good & $118-156$ & 47 & 69,12 \\
\hline & & Total & 68 & 100
\end{tabular}

The data in Table I shows that students in the Department of Environmental Health Polytechnic of the Ministry of Health of Pontianak have a perception about the quality of education services in the good and very good category. Most of the students, as many as 47 people $(69.12 \%)$ had the perception that the quality of education services which included aspects of the reliability, assurance, appearance, and attention in the Department of Environmental Health at the Pontianak Health Ministry Polytechnic was very good.

Analysis of perception description about the quality of education services obtained results as can be seen in Figure 1.

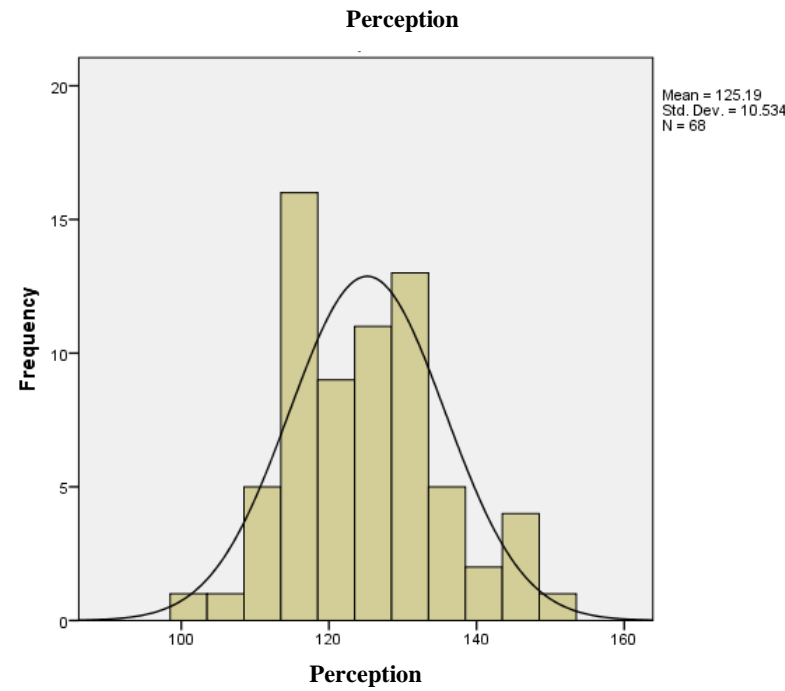

Fig. 1 Histogram of Perception Variables about the Quality of Education Services

Based on Figure 1 it can be seen that the perception variable about the quality of education services has data obtained in the study derived from 68 respondents with an average score of 125.19, a standard deviation of 10.534 with a variant of 110.963, has a minimum score of 101 and a maximum of 153 . The results of the calculation of the amount The total theoretical score $(68 \times 39 \times 4)$ is 10,608 and the total empirical total score is 8,513 , then the percentage of perception variables about the 
quality of education services is $(8,513 / 10,608) \mathrm{x}$ $100 \%=80,25 \%$. It shows that students' perceptions about the quality of education services which include aspects of trustworthiness, assurance, appearance, and attention in the Department of Environmental Health in the Pontianak Health Ministry Polytechnic can be categorized very well because they are in the range of $75-100 \%$.

2. Organizational Environment in the Department of Environmental Health Pontianak Health Ministry Polytechnic

Organizational environment variables consist of 42 statement items using four choice scales (1-4). Organizational environment can be grouped into four categories: poor with a range of total scores $(0-42)$, moderate $(43-84)$, good $(85-126)$, and very good (127-168).

The frequency distribution grouping as can be seen in Table II.

Table II

Environment Frequency Distribution of Organizations by Category

\begin{tabular}{cllcc}
\hline No & Category & Score Range & Frequency & Percentage \\
\hline 1 & Poor & $0-42$ & 0 & 0 \\
\hline 2 & Fair & $43-84$ & 0 & 0 \\
\hline 3 & Good & $85-126$ & 14 & 20,59 \\
\hline 4 & Very Good & $127-168$ & 54 & 79,41 \\
\hline & & Total & 68 & 100 \\
\hline
\end{tabular}

The data in Table II shows that students feel the organizational environment in the Department of Environmental Health of the Pontianak Ministry of Health Polytechnic is in the good and very good category. Most students, as many as 54 people $(79.41 \%)$ felt that the organizational environment which included aspects of the physical environment, social environment, affective environment, and academic environment in the Department of Environmental Health at the Pontianak Health Ministry Polytechnic was in the very good category.

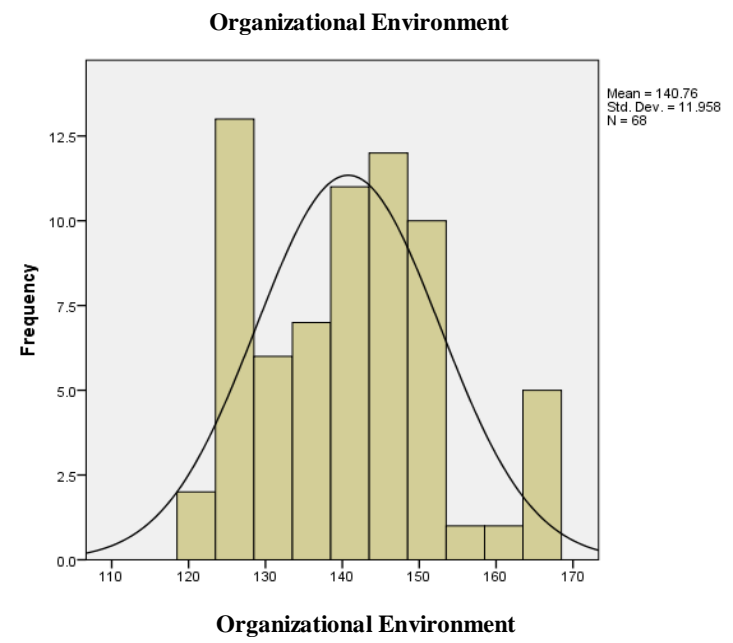

Fig.2 Histogram of Organizational Environment Variables
Based on the histogram can be seen that the organizational environment variable has the data obtained in the study came from 68 respondents with an average score of 140.76, a standard deviation of 11.958 with 142.989 variants, have a minimum score of 121 and a maximum of $167.68 \times 42 \times 4$ ) is 11,424 and the total empirical total score is 9,572 , then the percentage of organizational environment variable is $(9,572 / 11,424) \times 100 \%=83,79 \%$. It shows that the organizational environment which includes aspects of the physical environment, social environment, affective environment, and academic environment is felt by students of the Environmental Health Department in the Pontianak Ministry of Health Poltekkes can be categorized very well because it is in the range of $75-100 \%$.

3. Achievement Motivation at the Pontianak Department of Health Poltekkes Environmental Health Department

Achievement motivation variables consist of 38 statement items using four choice scales (1-4). Achievement motivation can be grouped into four categories: low with a range of total scores $(0-38)$, moderate (39 - 76), high (77 - 114), and very high (115-152).

The frequency distribution grouping as can be seen in Table III.

Table III

Frequency Distribution of Achievement Motivation by Category

\begin{tabular}{cllcc}
\hline No & Category & Score Range & Frequency & Percentage \\
\hline 1 & Poor & $0-38$ & 0 & 0 \\
\hline 2 & Fair & $39-76$ & 0 & 0 \\
\hline 3 & Good & $77-114$ & 13 & 19,12 \\
\hline 4 & Very Good & $115-152$ & 55 & 80,88 \\
\hline & & Total & 68 & 100
\end{tabular}

Data in Table III shows that students in the Department of Environmental Health Polytechnic of the Ministry of Health of Pontianak have high motivation to achieve high and very high categories. Most of the students in the Department of Environmental Health Polytechnic of the Ministry of Health of Pontianak, as many as 55 people $(80.88 \%)$ had achievement motivation in the very high category.

Analysis of description of achievement motivation obtained results as can be seen in Figure 3. 


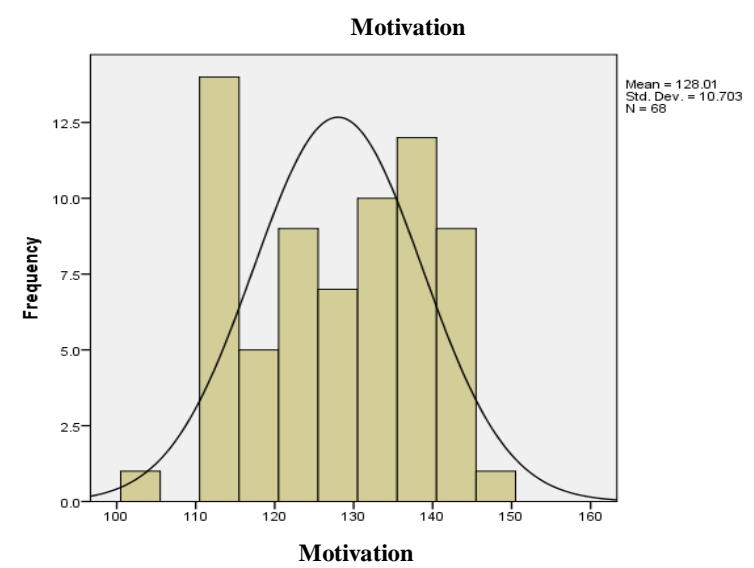

Fig. 3 Histogram of Achievement Motivation Variables

Based on the histogram it can be seen that the achievement motivation variable has the data obtained in the study from 68 respondents with an average score of 128.01 , a standard deviation of 10.703 with a variant of 114.552 , has a minimum score of 103 and a maximum of 146. The results of the calculation of the total theoretical score $(68 \times 38$ $\mathrm{x} 4)$ is 10,336 and the total empirical total score is 8,705 , then the percentage of achievement motivation variables is $(8,705 / 10,336) \times 100 \%=84,22 \%$. It shows that the achievement motivation of Environmental Health Department students in the Pontianak Ministry of Health Poltekkes can be categorized as very high because it is in the range of $75-100 \%$. It can be interpreted that students have very high motivation regarding responsibility, confidence, moderate risk taking, require immediate feedback, are not satisfied with accidental achievement of success, prioritize satisfaction overachievement rather than reward, engrossed in work, love challenges, and initiatives, and do planning in doing activities.

1. Data Analysis Test Requirements

\section{a. Data Normality Test}

Data normality test is used to find out whether the data is normally distributed or not. The following is presented the results of the research normality test using SPSS 22 for Windows program. The statistical normality test used in this study is Kolmogorov Smirnov because the sample is more than 50. The data is said to be normally distributed if the Asymp sig value is $>0.05$. Based on the statistical analysis presented in the tables above, it is known that the perception variables regarding the quality of education services $(p=0.065)$ and organizational environment $(p=0.181)$ have data that are normally distributed. While the variables of achievement motivation have abnormal data distribution $(\mathrm{p}=0.12)$ and after being also transformed still have abnormal data distribution $(\mathrm{p}=0.06)$

\section{b. Linearity Test}

Data linearity test is a statistical test that aims to determine whether two variables have a linear or not significant relationship which is a prerequisite of correlation analysis. The results of the linearity test data show that the relationship between perception variables about the quality of education services and achievement motivation is linear because of the significance value of deviation from linearity $0.330(>0.05)$, as well as the relationship between environment variables of organizations with achievement motivation that have significant value on deviation from linearity 0.547 (> 0.05).

2. Hypothesis Testing

Testing the hypothesis in this test is to determine the effect of perception variables on the quality of education services (X1) on achievement motivation variables $(\mathrm{Y})$, the influence of organizational environment variables (X2) on achievement motivation variables (Y), as well as the influence of perception variables on the quality of education services ( X1) and organizational environment variable (X2) together with achievement motivation.

The results of hypothesis testing are said to have a significant correlation between variables if the value of $p<0.05$. The direction of correlation consists of positive (unidirectional) and negative (opposite). A positive correlation direction means that the greater the value of one variable the greater the value of other variables, while the direction of negative correlation means that the greater the value of one variable the smaller the value of the other variable. The strength of the correlation between these variables can be known by looking at the value of $r$.

For more details the results of testing the hypothesis between the variables mentioned above will be explained below:

a. The Influence of Perceptions about the Quality of Education Services (X1) on Achievement Motivation (Y)

Based on the normality test, it is known that the distribution of perception variable data about the quality of education services is normal, while the achievement motivation variable has an abnormal distribution. Therefore, the hypothesis test used is the Spearman correlation to determine whether there is an influence of perceptions about the quality of education services (X1) on achievement motivation (Y). The results of the statistic test correlation between $\mathrm{X} 1$ and $\mathrm{Y}$ obtained a significance value of $p=0,000(p<0.05)$, which indicates that the correlation between perceptions of the quality of education services and achievement motivation 
is meaningful. Spearman correlation value of 0.445 indicates that the direction of positive correlation with the strength of correlation $(r)$ is moderate (0.40-0.599). It can be interpreted that the better student perceptions about the quality of education services in the Department of Environmental Health at the Pontianak Ministry of Health Poltekkes, the higher the student achievement motivation.

b. Effect of Organizational Environment (X2) on Achievement Motivation (Y)

Based on the normality test it is known that the distribution of organizational environment variable data is normal, while the achievement motivation variable has an abnormal distribution. Therefore the hypothesis test used is the Spearman correlation to determine whether there is an influence of perceptions about the quality of education services (X2) on achievement motivation (Y). The results of the statistic test correlation between $\mathrm{X} 2$ and $\mathrm{Y}$ obtained a significance value of $p=0,000(p<0.05)$, which indicates that the correlation between the environment of the organization and achievement motivation is meaningful. Spearman correlation value of 0.767 shows that the direction of the correlation $(r)$ is positive with a strong correlation strength (0.600.799). It can be interpreted that the better the organizational environment in the Ministry of Health's Environmental Health Department in Pontianak, the higher the student achievement motivation will be.

c. The Influence of Perceptions About the Quality of Education Services (X1) and Organizational Environment (X2) Together Against Achievement Motivation (Y)

Hypothesis testing is used to determine the effect of perceptions about the quality of education services and organizational environment together on achievement motivation, namely linear regression. The results of the analysis with the SPSS program obtained data that the influence of perception variables on the quality of education services and organizational environment together on achievement motivation showed $\mathrm{p}$-value $=0,000$ ( $p<0.05)$. Thus it can be concluded that there is a significant influence jointly between perceptions of the quality of education services and organizational environment on achievement motivation. It can be interpreted that the better student perceptions about the quality of education services and organizational environment in the Department of Environmental Health of the Pontianak Ministry of Health Polytechnic, the higher the student motivation will be. In addition, table 4.22 also shows the amount of $\mathrm{R}=0.779$, which means that the magnitude of the influence of perception variables on the quality of education services and organizational environment together on achievement motivation is $77.9 \%$.

\section{B. Discussion}

Statistical analysis on the results of the research described in the previous chapter shows findings that are answers to the formulation of research problems. The main problem of this research has been answered, namely the perception of the quality of education services and organizational environment positively and significantly correlates with achievement motivation. It can be taken into consideration for educational institutions, especially the Environmental Health Department of the Pontianak Ministry of Health Poltekkes regarding increasing student achievement motivation.

The next discussion will be explained further about the relationship of each variable, namely the influence of perceptions about the quality of education services on achievement motivation and organizational environment on the achievement motivation of students of the Environmental Health Department of the Ministry of Health Poltekkes Pontianak.

1. Effect of Perceptions on the Quality of Education Services on Achievement Motivation Students at the Pontianak Ministry of Health Poltekkes Environmental Health Department

The results of the study as presented in table 4.20 prove the existence of a positive and significant influence on students' perceptions of the quality of education services in the Department of Environmental Health on student achievement motivation with moderate correlation strength $(\mathrm{r}=$ 0.445). It means that the better the student's perception of the quality of education services, the higher the achievement motivation will be. The results of this study are in line with research conducted by Ummu Muntamah, Harbandinah P., and Laksmono W. which describes the relationship between student perceptions of the quality of education services to motivation following the teaching and learning process, as well as the quality of lecturer service which is part of the quality of educational services. Most dominant as a predictor of an increase in student motivation. Likewise, the research conducted by Lita $\mathrm{H}$. Wulandari and Fasti Rala (2004) on self-concept and adolescent achievement motivation in the orphanage which is a type of correlational research shows a positive relationship between self-concept and achievement motivation.

Perception plays an important role in shaping behavior. As the opinion of Robbins and Judge (2014: 175) suggests that perception is a process by which individuals regulate and interpret sensory impressions to give meaning to the 
environment. In line with the presentation of Triatna, C. which defines perception as a process of thought and feeling which then becomes the basis for consideration of behaving.

Quality or quality of service is a presentation of a product or service in accordance with the applicable size and at least equal to consumer expectations. The service is said to be qualified according to Tenner and Toro (in Maswardi M. Amin), namely if it fulfills the characteristics of reliability, assurance, appearance (tangibles), attention (empathy), and responsiveness (responsiveness). In the field of education, the quality of educational services will assure educational processes or services in educational institutions in accordance with established standards and are able to meet the wishes of students, the community and other related parties (customer satisfaction). The form of educational services in educational institutions leads to learning services in which there is a reciprocal relationship between educators and students. This reciprocal relationship is influenced by how students' perceptions of the scope of education include infrastructure as supporting teaching and learning activities, lecturers as educators, and other supporting personnel who are in the education sector.

A person's perception of an object is different. Therefore perception has a subjective nature. Likewise, students' perceptions of a quality education service between one student and another student will vary, so this will also lead to differences in encouragement or motivation in the student in carrying out activities in an educational institution. It can be interpreted that if students have an assessment that an educational institution is able to provide quality services in the sense of fulfilling their needs in carrying out the education period to cause satisfaction, then it will directly encourage them in achieving their expectations to be superior.

2. Effect of Organizational Environment on Achievement Motivation Students at the Pontianak Department of Environmental Health Polytechnic of Health

The results of the study as presented in table 4.21 prove the existence of a positive and significant influence on the organizational environment in the Department of Environmental Health of the Pontianak Ministry of Health Polytechnic on student achievement motivation with strong correlation strength $(r=0.767)$. It means that the better the organizational environment in the Department of Environmental Health, the higher the student achievement motivation will be. Environmental Health Department Pontianak Health Ministry Polytechnic is a college. Higher education is one form of organization, so if you want to understand about the organizational environment in higher education, it can be through understanding of the environment of the organization itself. Organizational environment influences behavior, as Gilmer's opinion on organizational environment understanding is "the set of enduring characteristics that describe an organization and the influence of the behavior of the people in the organization." The organizational environment can be interpreted as the condition or atmosphere of the organization that is felt by its personnel towards the organizational environment, be it physical, social, affective or academic environment, where these conditions are felt individually.

An organizational environment that leads to positive things, of course, will create a conducive organizational environment, where personnel in the organization will be able to feel a school environment that is safe, clean, beautiful, regulated, and harmonious family relationships between personnel and guaranteed comfort and safety. This conducive organizational environment will influence every personnel to actualize ideas, creativity, innovation, cooperation, and healthy competencies in the pursuit of achieving goals.

The above description can be interpreted as a good organizational environment in the Department of Environmental Health of the Pontianak Ministry of Health Polytechnic will create reciprocal relationships that support each other so that they can encourage to achieve the expected goals. Especially for students, this expected goal certainly has achievements that can be proud of as a form of achieving self-satisfaction in carrying out its education process, so that it can be said that a good organizational environment will shape achievement motivation.

3. Effect of Perceptions on the Quality of Education Services and Organizational Environment on Achievement Motivation of Students in the Department of Environmental Health Pontianak Ministry of Health Poltekkes

The results of the study prove that there are a positive and significant influence and organizational environment together in the Department of Environmental Health of the Pontianak Ministry of Health Polytechnic on student achievement motivation. It means that the better the student's perception of the quality of education services and the better the organizational environment in the Department of Environmental Health, the higher the student achievement motivation will be followed. As the opinion of Kreiner and Kinicki argues that perception is a cognitive process that allows us to interpret and understand the environment around us. In addition, it was explained earlier that perception also plays an important role in shaping behavior. A good organizational environment will create a conducive condition in the organization that allows its personnel to engage in better activities in achieving their desired goals. 
Likewise, it was also experienced by students of the Department of Health at the Pontianak Health Ministry Polytechnic. Based on the results of the study it can be seen that most students of the Department of Environmental Health, as many as 47 people $(69.12 \%)$ have a perception that the quality of education services is very good. It means that students feel that the Health Department provides or facilitates the needs they need in carrying out learning activities. In addition, most of the students, namely 54 people $(79.41 \%)$ felt that the organizational environment in the Department of Environmental Health Polytechnic of the Ministry of Health of Pontianak was categorized as very good, which meant that the condition or atmosphere of the environment in the Department of Health was conducive so as to provide security and comfort for students in carrying out activities as a student.

Because the two variables mentioned above are in a very good category, of course, it supports students to have high achievement motivation, as many as 55 people $(80.88 \%)$ have achievement motivation in the excellent category. This high achievement motivation makes students have the urge to be superior in achieving their desired goals. Heckhausen (in Djaali, 2017: 103) also explained that achievement motivation is an impulse found in students who always try to improve their abilities as high as possible in all activities by using standards of excellence. This standard of excellence includes the standard of excellence of duty, the standard of excellence of self, and the standard of excellence of other students.

The results of this study also showed the value of $R=0.779$ as described in table 4.22 which means the influence of perception variables on the quality of educational services and organizational environment together on achievement motivation is $77.9 \%$. It can be interpreted that achievement motivation is also influenced by other factors.

According to Sukadji (in Andriani, 2010) suggests the factors that influence achievement motivation, including the expectations of parents to their children, experiences in the first years of life, cultural backgrounds in which a person is brought up, imitation of behavior, and the environment in which the learning process take place

Furthermore, Kurniadin and Machali (2016: 351) explained that motivation according to the theory of the relationship between reward and achievement, one's motivation is influenced by various factors, both internal and external. As for those included in the internal factors are (1) one's perception of himself, (2) self-esteem, (3) personal expectations, (4) needs, (5) desires, (6) job satisfaction, (7) work performance generated. While the things that include external factors are (1) the type and nature of the work, (2) the workgroup where someone joins, (3) the organization of the workplace,
(4) the environmental situation in general, (5) the reward system that applies and the way application. According to Uno (2016: 4), intrinsic motivation is stronger than extrinsic. Therefore educational institutions must try to generate intrinsic motivation by fostering and developing participants' interest in the relevant fields of study.

\section{CONCLUSIONS AND SUGGESTIONS}

A. Conclusions

1. Most of the students, as many as 47 people $(69.12 \%)$ has a very good perception of quality services in the Department of Environmental Health, Pontianak Health Ministry Polytechnic.

2. Most of the students, as many as 54 people $(79.41 \%)$ felt that the organizational environment in the Department of Environmental Health at the Pontianak Health Ministry Polytechnic was in the very good category.

3. Most of the students in the Department of Environmental Health Polytechnic of the Ministry of Health of Pontianak, as many as 55 people $(80.88 \%)$ have excellent achievement motivation.

4. Perceptions of the quality of education services have a significant effect on student achievement motivation in the Department of Environmental Health of the Pontianak Ministry of Health Poltekkes. The correlation between the values of 0.445 shows that the direction of the positive correlation with the strength of the correlation is moderate (0.40-0.599).

5. Organizational environment has a significant effect on student achievement motivation in the Pontianak Department of Health Department of Environmental Health Poltekkes. The correlation of the value of 0.767 shows the direction of correlation $(r)$ is positive with strong correlation strength (0.60-0.799).

6. Perceptions of quality and organizational environment together have a significant effect on student achievement in the Department of Environmental Health of the Pontianak Ministry of Health Poltekkes. The strength of the relationship is the value of $\mathrm{R}=0.779$ which means that the magnitude of the influence of perception variables on the quality of educational services and organizational environment on achievement motivation is $77.9 \%$.

B. Suggestions

1. Health Department Pontianak Health Ministry Polytechnic must continue to maintain or even improve the quality of education services that have been perceived very well by students, especially those relating to campus facilities such as internet networks that can facilitate students to add insight and the latest knowledge. 
2. The Department of Environmental Health at the Pontianak Health Ministry Health Office always creates a conducive organizational environment so that the organizational environment that has been felt very well by students can be maintained so that the relationships between organizational personnel remain in harmony and harmony.

3. Environmental Health Department Pontianak Health Ministry Polytechnic can provide a suggestion box that can accommodate input from organizational personnel and follow up on positive input.

4. The Pontianak Department of Health's Environmental Health Department of Health Polytechnic facilitates students to get their rights as students such as the distribution of Study Results Cards (KHS) just in time so that students know their achievements/grades during learning so that they motivate them to become better.

\section{REFERENCES}

Amin, Maswardi M. dan Yuliananingsih. 2016. Manajemen Mutu; Aplikasi dalam Bidang Pendidikan. Yogyakarta: Media akademi.

Andriani, Fitri. 2010. Hubungan Persepsi Terhadap Peran Ayah Dengan Motivasi Berprestasi Siswa Mas Islamiah Sunggal. Fakultas Psikologi Universitas Sumatera Utara . (Online) Diakses 8 Januari 2018.

Bastian, Indra. 2006. Akuntansi Pendidikan. Jakarta: Erlangga.

Djaali. 2017. Psikologi Pendidikan. Jakarta: PT. Bumi Aksara.

Hoy, Wayne K. dan Miskel, Cecil G. 2014. Administrasi Pendidikan (Teori, Riset, dan Praktik). Terjemahan Daryatno dan Rianayati K. Pancasari. Yogyakarta : Pustaka Pelajar.

Kurniadin, Didin. dan Machali, Imam. 2016. Manajemen Pendidikan: Konsep dan Prinsip Pengelolaan Pendidikan. Jogjakarta: Ar-Ruzz Media.

Mulyana, Aina. 2016. Faktor-Faktor Yang Mempengaruhi Motivasi Belajar. http://ainamulyana.blogspot.com. Diakses pada 10 Mei 2017.

Muntamah, Ummu. (2012). Persepsi Mahasiswa Tentang Mutu Pelayanan Pendidikan dan Motivasi Mengikuti Proses Belajar Mengajar. Jurnal Promosi Kesehatan Indonesia Vol.7/No.2/Agustus 2012. ejournal.undip.ac.id/index.php/jpki/article/d ownload/5564/4946 Diakses pada 6 Februari 2018

Robbins, Stephen P., Judge, Timothy A., 2014, Organization Behaviour (12 $2^{\text {th }}$ Edition). Terjemahan Angelica, Diana., Cahyani,
Ria., Rosyid, Abdul. Jakarta : Salemba Empat.

Setya, Oktaviano Forman. 2015. Pengaruh Penghargaan dan Persepsi Terhadap Pekerjaan Terhadap Komitmen Organisasi Guru SMA Negeri di Jakarta Utara. Tesis. Program Pasca Sarjana Universitas Negeri Jakarta : Jakarta.

Wulandari, Lita H., Fasti Rala. 2004. Konsep Diri dan Motivasi Berprestasi Remaja Penghuni Panti Asuhan. Jurnal Pemberdayaan Komunitas. Volume 3 Nomor 3. Halaman 74-80. 